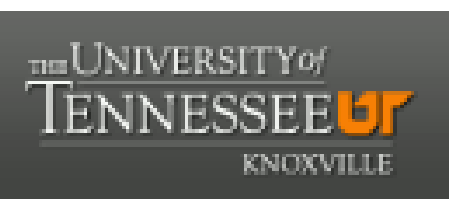

University of Tennessee, Knoxville

TRACE: Tennessee Research and Creative

Exchange

\title{
A Lexical Examination and (Unscientific) Survey of Expanded Clinical Experiences in U.S. Law Schools
}

Becky Jacobs

University of Tennessee, jacobs@utk.edu

Follow this and additional works at: https://trace.tennessee.edu/utk_lawpubl

Part of the Law Commons

\section{Recommended Citation}

Jacobs, Becky L., A Lexical Examination and (Unscientific) Survey of Expanded Clinical Experiences in U.S. Law Schools (July 27, 2008). Tennessee Law Review, Vol. 45, p. 343, 2008. Available at SSRN: https://ssrn.com/abstract=1136786 or http://dx.doi.org/10.2139/ssrn.1136786

This Publication is brought to you for free and open access by the Law at TRACE: Tennessee Research and Creative Exchange. It has been accepted for inclusion in College of Law Faculty Scholarship by an authorized administrator of TRACE: Tennessee Research and Creative Exchange. For more information, please contact trace@utk.edu. 
Symposium: Looking Forward: The Next Sixty Years of Clinical Legal Education

Symposium Articles

\title{
*343 A LEXICAL EXAMINATION AND (UNSCIENTIFIC) SURVEY OF EXPANDED CLINICAL EXPERI- ENCES IN U.S. LAW SCHOOLS
}

\author{
Becky L. Jacobs [FNa1] \\ Copyright (c) 2008 Tennessee Law Review Association, Inc.; Becky L. Jacobs
}

I. Introduction

The future ain't what it used to be.

Yogi Berra [FN1]

In September 2007, the University of Tennessee College of Law's Legal Clinic celebrated its sixtieth year of continuous operation. To mark this significant milestone, the College of Law hosted a Symposium that explored the future of clinical legal education-"Looking Forward: The Next Sixty Years of Clinical Legal Education." An impressive and diverse array of clinical scholars attended the event, many of whom participated on panels organized to highlight emerging issues for clinical programs.

One of these panels addressed the topic of "Expanding Clinical Experiences," and I was honored, and not a little intimidated, to join the impressive scholars who participated on this panel. [FN2] As I began preparing my remarks for the event, I was challenged by a common problem, a problem about which Symposium attendees debated and upon which this Essay will focus. That problem is one of definitions: How does one (and who should) define a clinical experience, how does one (and who should) organize and label clinical offerings, and how does one (and who should) define "clinician"?

*344 II. Definitions and Lexical Nuances; Or, A Clinic or Clinician by Any Other Name

Don't get me right, I'm just asking.

Yogi Berra

Definitional challenges pertaining to law school clinical programs arise in several contexts. In this Essay, I will focus on three particular lexical obstacles: (1) the precise characterization of the history of the University of Tennessee's (UT's) Legal Clinic, (2) the dichotomous and rather inexplicable nature of the relevant "specialty" rankings published by U.S. News \& World Report, and (3) the clinical offerings available to students at UT and other U.S. law schools. I also will mention the difficulties associated with identifying members of a law school's clinical faculty and why definitional issues may contribute to this difficulty.

\section{A. UT Legal Clinic's Historical Pedigree}


I wish I had an answer to that, because I'm tired of answering that question.

Yogi Berra

I stumbled onto the first definitional challenge when reviewing the venerable history of UT's Legal Clinic. This Symposium commemorated the Clinic's sixtieth anniversary. We here at UT are almost annoyingly, but justifiably, proud to say that our Clinic is one of the country's oldest [FN3] and most successful programs of its kind. Definitional challenges, however, require precision when claiming and describing our historical pedigree.

Program characteristics and nuances account for this need for linguistic precision. Since the late 1800s, law schools have flirted with experiential learning programs. [FN4] Indeed, most historians have identified the "legal dispensary" operated by students at the University of Pennsylvania Law School in 1893 as the first law school clinical program. [FN5] A number of law schools established similar programs over the next couple of decades. [FN6] These primarily extracurricular, non-credit programs were run by students and were voluntary. [FN7] UT students were among this vanguard of the non-credit clinical movement. *345 First-year students established the Free Legal Aid Bureau in 1915 and pledged to " spend a certain amount of time each week in the assistance of the poor and needy citizens of Knoxville, whose wrongs would otherwise go without righting."” [FN8]

The University of Southern California experimented with a for-credit law school clinical program in the late 1920s. [FN9] In this program, which lasted only six weeks, students earned credit for work at the Los Angeles Legal Aid Foundation. [FN10] (Stay with me here; I have almost reached the basis for UT's boast.) Duke University established the first for-credit, in-house legal clinic in 1931 [FN11] but eliminated it twenty-eight years later. [FN12] It was in 1947 that UT created its for-credit in-house clinic, a clinic that, as commemorated by this Symposium, still is going strong today. [FN13] These sixty years of operation give UT's Clinic bragging rights as the oldest continuously operating legal clinic in the nation. [FN14]

Since the creation of the UT Clinic in 1947, many have reported on the development of clinical legal education programs in U.S. law schools. [FN15] Clinics now have become an integral part of the curriculum at nearly every law school in the nation. [FN16] The recent report on legal education by the Carnegie Foundation for the Advancement of Teaching recognized "the potential of clinical-legal education for bringing together the multiple aspects of legal knowledge, skill, and purpose." [FN17]

Indeed, all ABA-accredited law schools must "offer substantial opportunities for . . . live-client or other reallife practice experiences, appropriately supervised and designed to encourage reflection by students on their experiences and on the values and responsibilities of the legal profession, $\mathbf{* 3 4 6}$ and the development of one's ability to assess his or her performance and level of competence." [FN18] Law schools have responded to this requirement by creating a dizzying array of clinical offerings with subject matters encompassing the full panoply of legal practice areas and with names that appear to have been assigned without reference to any consistent coding convention or organizing principles.

The fine distinction with which we at UT refer to the pedigree of our Clinic does not in any way diminish the significant accomplishment that these historical facts represent. It does, however, illustrate the nuances of nomenclature that abound in the literature reporting on and describing law school legal clinics in general and clinical offerings in particular. While clinicians ostensibly are armed with a "common vocabulary," [FN19] that vocabulary is rich and textured, replete with subtle synonyms confusing to those not steeped in the parlance of clinical practitioners. The next sections explore in more detail the challenges of mastering this vocabulary. 


\section{B. U.S. News Law School Specialty Rankings}

I knew exactly where it was, I just couldn't find it.

Yogi Berra

A second definitional issue arose when I consulted the much reviled, yet feared, U.S. News \& World Report rankings for clinical programs. [FN20] U.S. News ranks "Clinical Training" programs at "America's Best" law schools, a list on which UT ranks a respectable number 16. [FN21] There is, however, a separate ranking for "Dispute Resolution" programs. [FN22]

*347 I preface all that follows by declaring my sincere regard for all of the law schools that appear on both the Clinical Training and Dispute Resolution lists. Regardless of the precise criteria by which schools are judged, academics would likely agree that the ranked schools do indeed merit their inclusion on a list of "America's Best" in their respective specialties. (Well, except for the travesty that UT is not ranked in the Dispute Resolution category!)

Thus, while I believe that I instinctively "know it when I see it" [FN23] and understand the programmatic distinction between these two specialties, the lexical characterization somewhat escapes me, and for the uninitiated, it might be even more inexplicable. Why, a neophyte might ask, is Dispute Resolution (DR) a separate specialty? Are clinics not the crucible where students learn dispute resolution in all of its forms?

This blurring of distinctions is apparent if one adopts Marc Galanter's conception of "litigotiation," his neologism for "a single process of strategic maneuver and bargaining in the (actual or threatened) presence of courts." [FN24] As Professor Galanter reminds us, most cases do not proceed to a full-blown adjudicative proceeding; "[s]ettlement is not an 'alternative' process, separate from adjudication, but is intimately and inseparably entwined with it." [FN25] If this is so, clinics are DR labs that offer students the opportunity to experience multiple stages of the single "litigotiation" process.

This conceptualization appears to comport with the way many academics who research and write on DR topics view the relationship of traditional models of adjudication, such as litigation, to so-called "alternative" DR processes. [FN26] For example, Professor Leonard Riskin and his co-authors illustrate "The Conflict Resolution Continuum" in their casebook, Dispute *348 Resolution and Lawyers. [FN27] At the far left of this Continuum are the "Consensual Processes," beginning with negotiation. Mediation appears just to the right of this. [FN28] Moving further to the right, the Continuum identifies the "Adjudicatory Processes" of arbitration and, finally, trial. [FN29]

In a clinical setting, students encounter these integrated approaches to DR routinely; therefore, the U.S. News Dispute Resolution specialty ranking could be considered redundant to the Clinical Training category. Of course, the Clinical Training category may not take into account a law school's non-clinical offerings that pertain to DR-consistent with an "I know it when I see it" approach. It is this, I presume, that distinguishes the two specialties in the minds of those who rank. [FN30] Arguably, and I know that I am spouting heretical crazy talk here, if a law school does not have strong curricular offerings in alternative dispute resolution (ADR) topics as well as in traditional litigation-related subjects, the educational value of a clinical experience to students might be somewhat diminished.

It is interesting to compare the schools that appear on the U.S. News Clinical Training list with those ranked for Dispute Resolution and to note that there is overlap. For example, in 2007, six of the fifteen schools ranked in the Dispute Resolution category also were ranked on the Clinical Training list: Harvard University, Yeshiva 
University (Cardozo), Fordham University, Georgetown University, University of Nevada-Las Vegas (Boyd), and Northwestern University. [FN31] Even if one does not agree that the specialties are $* \mathbf{3 4 9}$ redundant, this overlap suggests at a minimum that there are definite synergies between these two specialties that improve the overall quality of both programs.

It follows, then, that those schools that appeared on the Dispute Resolution list but not on the Clinical Training list must have some characteristic that distinguishes them from the many other schools with excellent and strong DR curricular offerings and faculty. [FN32] Several factors may be relevant, such as the presence of a DR Institute or Center at the school; [FN33] the school's publication of a DR journal; [FN34] a school's LLM, certificate, or concentration in DR; [FN35] or the reputation of a school's DR faculty. [FN36]

*350 The influence of these factors and of non-clinical courses related to clinical offerings on the Dispute Resolution specialty rankings raises yet another issue that is embedded in this query: What is the very basic definition of a "clinic"? The ABA Standards for Approval of Law Schools do not define the term. As previously mentioned, Standard 302(b)(1) requires that all ABA-accredited law schools offer "substantial opportunities for . . . live-client or other real-life practice experiences, appropriately supervised and designed to encourage reflection." [FN37] Interpretation 302-5 of that Standard notes that law schools might fulfill this requirement through "clinics or field placements." [FN38] Except for rather unhelpfully acknowledging that there is a distinction between a clinic and a field placement, this Interpretation leaves the ultimate definitional issue unresolved.

The Association of American Law Schools (AALS) definition seems to be the most commonly cited. In its 1992 report on future of in-house clinics, it stated that

[c]linical education is first and foremost a method of teaching ... [by which] students are confronted with problem situations of the sort that lawyers confront in practice; the students deal with the problem in role; the students are required to interact with others in attempts to identify and solve the $* \mathbf{3 5 1}$ problem; and, perhaps most critically, the student performance is subjected to intensive critical review. [FN39]

Although oft-cited, this description focuses more on method than form and fails to clarify the precise boundaries of a "clinic." This formulation appears to encompass the "three different branches of clinical education in the United States: in-house live-client clinics, externship programs, and simulation courses." [FN40] Other commentators view clinical education more narrowly and would refine the definition componentially:

[A] law school clinical program would have six components. First, it is created through a law school with the intent that the program be integrally linked to the academic program of the institution. Second, law students, usually in their final years of law school, learn experientially by providing legal services or advice to real clients who qualify for representation by the law school's clinic. Third, those students are closely supervised by an attorney admitted to practice in the relevant jurisdiction, preferably by a member of the law school faculty or a private practitioner, who shares the pedagogical objectives of the clinical experience. Fourth, the clients served by the clinical program generally are not able to afford the cost of hiring private counsel, and they usually come from traditionally disadvantaged, underserved or marginal sectors of the community. Fifth, supervised case representation by students is preceded or accompanied by a pedagogical program that prepares students in what might be called theories of the practice of law. This would include components of substantive doctrine, skills, ethics, and values of law practice, and would be taught by a professor who knows the students' cases well enough to integrate that experience into the clinic classroom. Sixth, the students would receive academic credit toward graduation, hopefully for both the case and class-work they undertake as part of their participation in a clinic. [FN41] 
*352 This debate, [FN42] while certainly of interest to academics, is not merely academic, and it has repercussions for a law school's curricular choices and categorical decisions. UT, for example, offers a number of "courses" that incorporate a clinical component, although they are not listed as part of our clinical program. Before the remarkable Fran Ansley [FN43] retired, she taught several courses at UT in which students collaborated with individuals in underrepresented communities to explore various dimensions of law and the legal system through research, education, or participation in mounting justice claims. [FN44] My ethics guru colleague Carl Pierce also has offered a course in which students supported the work of a Tennessee Bar Association committee charged with improving underrepresented parties' access to justice. Based upon the AALS definition of the term, all of these courses legitimately could be considered "clinics," yet UT did not categorize them as such.

Other law schools, however, may decide that similar curricular selections are more appropriately included on the roster of their clinical programs, and each law school likely would assign a unique descriptive label to similar course selections. While clinicians claim to be "[e]quipped with a "common vocabulary' and a generally accepted definition of a methodology," [FN45] a quick glance at the plethora of "clinics" offered by law schools in the United States reveals that the definitional/categorical issue is still largely unresolved, the topic addressed in the following section.

\section{*353 C. Law School Clinical Offerings}

If you don't know where you are going, you will wind up somewhere else.

Yogi Berra

The third lexical conundrum that I [FN46] encountered concerns the diversity of clinical offerings available to students at UT and other U.S. law schools. To collect the data reported in this Essay, I identified all of the clinical offerings listed on the websites of each of the top 100 U.S. law schools, as ranked by U.S. News. My goal was to catalogue the data to determine what types of clinics were widely available, what offerings were new and interesting, and what trends might appear.

What I discovered is that clinicians are a very creative and energetic bunch and that U.S. law students have access to numerous, richly diverse clinical opportunities. However, because there was no consistency to the way in which law schools refer to or denominate their clinical offerings, I was left to struggle to create somewhat arbitrary categories into which to fit each of the incredibly diverse programs that I found. This categorization was further complicated by each school's treatment of its externship and field placement programs. [FN47] Again, there did not appear to be an established methodology to differentiate between clinics and externships, and the ABA Standards provided little guidance.

*354 With those caveats in mind, I will attempt to report on the collected data. [FN48] First, depending upon how one counts, there are upwards of 523 separate in-house, live-client clinical offerings at the top 100 U.S. law schools. The most common clinics (ninety or so) involve some sort of civil practice, such as landlord-tenant and domestic relations work. Other civil offering designations include "Civil Litigation" clinics, [FN49] "Small Claims" clinics, [FN50] and "General Practice" clinics. [FN51]

Various types of criminal clinics are also common; there are between sixty and seventy-five, again depending upon how one counts. These clinics cover the criminal law waterfront, engaging in both prosecution and defense work, trial and appellate. Students can work on death penalty cases, [FN52] innocence projects, [FN53] inmate and family matters, [FN54] and parole issues, [FN55] among other topics. 
Many schools-approximately thirty-six-list juvenile clinics as a separate offering. The subject matters vary, including abuse and neglect, delinquency, termination of parental rights, and criminal/juvenile justice. [FN56] Other clinical programs conduct legal work in support of children, including children's rights clinics [FN57] and special education advocacy. [FN58]

*355 Clinics related to immigration and refugee law; to community and economic development, nonprofits, and business planning; to ADR-related legal work; and to environmental law also are popular. Over thirty clinics pertain to immigration, refugee matters, or both, [FN59] and about forty clinics engage in some form or combination of nonprofit, economic development, or small business planning. [FN60] Roughly thirty-one clinics focus on negotiation, mediation, or ADR [FN61] and over twenty specialize in environmental work. [FN62]

The variety of available specialty clinics is inspiring, and I will just mention a few that caught my eye. Seizing an opportunity, several Iraqi Tribunal Clinics [FN63] and hurricane relief clinics [FN64] have been formed. Several gay, lesbian, bisexual, and transgender (GLBT) clinical programs, [FN65] an HIV/AIDS clinic, [FN66] and a vaccine injury clinic [FN67] also exist, as well as offerings devoted to $* \mathbf{3 5 6}$ tobacco control, [FN68] investor justice, [FN69] the arts, [FN70] and sexual violence. [FN71] Other, more common specialty clinics include those devoted to community lawyering, [FN72] taxpayers, [FN73] health law, [FN74] international human rights, [FN75] legislative advocacy, [FN76] and administrative/government benefits representation, including disability, [FN77] workers' compensation, and welfare.

Of course, all of my musings are dependent upon my interpretive decision regarding how best to classify each law school's clinical offerings. It may be that I make much of a "unique" clinic that, in fact, is replicated at other law schools, lacking only an interesting, eye-catching name. This lack of a common lexicon for clinical offerings could be problematic in a number of contexts, not the least of which is the challenge that it presents to those humble souls collecting empirical data.

Another more serious concern is the lack of transparency for potentialapplicants. Law students are consumers and, like all consumers, may be susceptible to attractively packaged and cleverly marketed products. [FN78] While *357 law schools justifiably take pride in the breadth and depth of their clinical programs, it behooves neither law schools nor potential applicants to encourage enrollment based upon an uninformed besottedness with the name of a clinic. Appealing apperception does not necessarily convey the subject matter coverage accurately, nor does it always commensurate with clinical quality, particularly to the uninitiated. As a clinic's title may potentially be misleading, so too can the titles of its directors or instructors, the topic of the next section.

\section{Law School Clinical "Faculty"}

In theory there is no difference between theory and practice.

In practice there is.

Yogi Berra

My final thoughts pertain to the complexities associated with identifying the members of a law school's clinical faculty and to the reasons why definitional issues may contribute to this difficulty. One would assume that it would be a relatively easy task to locate the members of a law school's clinical faculty. Yet, for a variety of reasons, this is not so. For example, many law schools do not list their clinical faculty separately on faculty rosters, or they may not name a clinic director or instructors with the description of a clinic course in order to provide flexibility in staffing. 
UT is a case in point, as the description of UT's Mediation Clinic does not identify me as the instructor. [FN79] Nor does UT's website distinguish in any way its full-time clinical faculty, all of whom are either tenured or tenure-track, from the remaining members of the full-time faculty. This, however, is not true at every law school, a fact that may complicate the nomenclature issue.

The debate continues over ABA Standard 405(c), which states that:

A law school shall afford to full-time clinical faculty members a form of security of position reasonably similar to tenure, and non-compensatory perquisites reasonably similar to those provided other fulltime faculty members. A law school may require these faculty members to meet standards $* \mathbf{3 5 8}$ and obligations reasonably similar to those required of other full-time faculty members. However, this Standard does not preclude a limited number of fixed, short-term appointments in a clinical program predominantly staffed by full-time faculty members, or in an experimental program of limited duration. [FN80]

Kim Diane Connolly raised this issue in her thought-provoking discussion at the Symposium, [FN81] reminding us that some law schools still maintain some form of differentiated tenure for clinical faculty or offer clinic instructors contracts that comply with the last sentence of ABA Standard 405(c). [FN82] If a law school lists only full-time, tenure-track faculty on its website or other routes of public access, clinic faculty may be impossible to identify.

Another complication may arise when law school doctrinal or classroom faculty [FN83] also teach in the clinic. I am one such faculty member. While I direct UT's superb Mediation Clinic, I do not teach full-time in the clinic, nor did I $* 359$ specialize in trial work in law school or in practice. Because of my law school experience and my professional conditioning, I somehow feel that I have not earned the right to have the title of "clinician" bestowed upon me, and I still pinch myself with glee every time that the Clinic faculty here claim me as their own. And I am not alone among many traditional "classroom instructors" joining the clinical fray. Indeed, there appears to be an increasing and varied level of participation by classroom faculty in the work of law school clinical programs, [FN84] a trend for which several causes have been ascribed and of which there may be various consequences.

ABA Standard 302(b)(1) [FN85] has been identified as one possible cause of the increasing involvement of classroom instructors in law school clinics. The ABA Standard's mandate that law schools "offer substantial opportunities for . . live-client or other real-life practice experiences" [FN86] has placed enormous demands not only upon law school clinical faculty, but also upon administrations and budgets. Compliance with the Standard requires creative solutions, one of which may be to draw upon all available resources to do so, including classroom instructors. My colleague Carl Pierce discussed this concept during his Symposium presentation, in which he urged the expansion of collaborative clinical offerings between classroom and clinical faculty. [FN87] Carl mentioned a number of interesting possibilities, including a clinical collaboration between a family law instructor and a mediation clinical supervisor in which students would offer mediation services to unrepresented divorcing parties and provide "limited scope" representation to assist them in filing any resulting settlement agreements. [FN88]

Collaborative endeavors such as these would be a wonderful, enriching experience for students. However, scholars have warned of serious consequences from classroom faculties' participation in law school clinical programs. For example, this collaboration could "raise[] important . . . ethical issues that may significantly affect faculty, students and clients." [FN89] 
One such ethical issue is the possibility that classroom faculty could be civilly or criminally liable for the unauthorized practice of law. [FN90] Classroom $* \mathbf{3 6 0}$ faculty who are not currently licensed to practice in the state in which their school is located could potentially face criminal charges for violating the state's unauthorized-practice-of-law statute. [FN91] Classroom faculty also could be subjected to disciplinary charges, both in the state in which their school is located and the state or states in which they are licensed. [FN92] Further, clinical faculty colleagues also could be penalized, as ethical rules forbid licensed attorneys from assisting a person in the unauthorized practice of law. [FN93]

Additionally, the involvement of classroom faculty in a law school clinic could result in breaches of client confidentiality or waiver of privileges. [FN94] Depending upon the specific role that classroom teachers play in a clinic-whether they act as practicing attorneys or as consultants or experts-the clinic and the classroom teachers must remain mindful not only of the obligations of confidentiality, [FN95] but also of attorney-client [FN96] and work product [FN97] privileges.

Conflicts of interest also may be a concern when classroom faculty participate in clinical programs, sometimes even requiring disqualification of the clinic as counsel for the client. [FN98] The particular conflicts that may arise as a result of collaborations between clinical and classroom faculty reflect the atypical structure of the law clinic as compared to other law firms [FN99] and make it very difficult to provide meaningful procedures for conflict checks. It is easy to imagine a classroom instructor being approached by a student with a work-related question that involves a matter to which the clinic might be adverse, particularly in smaller communities. [FN100]

Further, while classroom faculty bring a wealth of substantive legal expertise and instruction experience to their clinical teaching, they often have little or no experience in litigation or case management. This poses a number of problems for clinical administrators, students, and clients, not to mention for transitioning classroom instructors. First, "[n]o clinician wants clients to suffer or students to be embarrassed because the supervisors as well as the student are utter novices in the clinic's area of practice." [FN101] To avoid this situation, new clinical teachers should receive training in the subject matter of the clinic as $* \mathbf{3 6 1}$ well as in the practice norms and rules of the courts in which they will be practicing and supervising students. [FN102]

Also, as one clinical scholar describes, "the process of teaching litigation (or other skills) is rather different from handling cases." [FN103] Thus, to guide and supervise students effectively, new clinicians should receive some training in clinical teaching. [FN104] Fortunately, this type of training is readily available. For example, the AALS offers training courses in clinical teaching. [FN105] Additionally, "[s]hort courses in the practice of nearly every kind of law are offered frequently by local bar associations, non-profit legal aid and other advocacy organizations, and specialized training groups such as the National Institute of Trial Advocacy." [FN106] It also may be feasible to allow transitioning faculty to observe proceedings of the type that they will encounter or to actually handle one or two cases, alone or with a more experienced practitioner. [FN107] Unlike my experience at UT, not all law schools offer their clinical faculty this type of preparation. Students at those schools may not find their clinical experiences as rewarding as do students at schools where clinical faculty have extensive experience with the subject matter and clinical teaching.

These concerns apply equally to the tireless and talented adjuncts upon whom schools often rely to provide support and supervision in our clinical programs. Returning to this Essay's definitional theme: How does one classify these talented adjuncts with regard to their faculty status? The ABA Standards would appear to allow adjunct faculty to supervise clinic students, [FN108] but most schools do not list adjuncts (or at least do not 
identify them as such) on their clinic websites, nor do they involve them in regularly scheduled faculty meetings or planning sessions. [FN109]

Most commentators acknowledge that "no resource is as critical [to a clinical program] as the teaching and support staff." [FN110] Accordingly, while my onomastic obsession may appear to be, well, obsessive, these lexical ambiguities are significant.

\section{*362 III. Conclusion}

It ain't over 'til it's over.

Yogi Berra

While I learned much during the UT Legal Clinic's sixtieth anniversary Symposium, I still have not resolved in my mind the question of how one defines and labels a clinical experience-or who that "one" should be. As I hope that I have suggested, the delicately nuanced taxonomy of clinic labels and the identification of clinical faculty are not merely "dancing on the head of a pin" [FN111] exercises and have implications beyond those academic.

That being said, what is most significant to me is the number and variety of clinics devoted to serving the underserved: the poor, the elderly, vulnerable youth, those in need of mental health services, farm workers, Native Americans, inmates, and ex-offenders, to name just a few. And, while there are those who claim that the AALS and ABA Guidelines for Clinical Legal Education settled the "service" versus "educational objective" issue, [FN112] clinicians not only teach students knowledge and skill, they also integrate valuable ethical and social concerns into the clinical experience. Bridget M. McCormack raised a similar point in her Symposium presentation; [FN113] participation in a law school clinic instills a sense of professionalism in students that cannot be learned or experienced in a classroom environment or simulated setting. The recent Carnegie Report also addresses the critical role that clinical education plays in teaching the ethical demands of practice and the virtues of a socially responsible practice of law, noting that "[c]linics can be a key setting for integrating all the elements of legal education, as students draw on and develop their doctrinal reasoning, lawyering skills, and ethical engagement, extending to contextual issues such as the policy environment." [FN114]

Clinicians are educators and public servants in the very real sense of those words. Their work impacts a broad spectrum of national and international issues as well as the lives and professional development of their students. $* \mathbf{3 6 3}$ However unworthy I feel to be included as part of UT's clinical faculty, I am honored and proud to be a part of this amazing group, however lexically categorized. I also am proud to have been a part of UT's sixtieth anniversary celebration and hope to be around for at least its seventy-fifth. Go Vols!

[FNa1]. Associate Professor of Law, University of Tennessee College of Law.

[FN1]. I have attempted to follow the venerable Doug Blaze tradition of referring to Yogi Berra. See, e.g., Douglas A. Blaze, Deja Vu All Over Again: Reflections on Fifty Years of Clinical Education, 64 Tenn. L. Rev. 939, 939 (1997).

[FN2]. See The University of Tennessee, Mediasite Presentations Catalog, http://mediabeast.ites.utk.edu/mediasite4/Catalog/ (follow "Charles Miller Legal Clinic-60th Anniversary Celebration” hyperlink in sidebar) (last visited Feb. 12, 2008). My co-panelists were Kim Diana Connolly, Associate 
Professor of Law and Director of the Environmental Law Clinic, University of South Carolina School of Law; Carl Pierce, W. Allen Separk Distinguished Professor of Law, The University of Tennessee College of Law; and Susan Deller Ross, Professor of Law and Director of the International Women's Human Rights Clinic, Georgetown University Law Center. Id.

[FN3]. Blaze, supra note 1, at 940 n.3.

[FN4]. See William P. Quigley, Introduction to Clinical Teaching for the New Clinical Law Professor: A View from the First Floor, 28 Akron L. Rev. 463, 467 (1995).

[FN5]. See Robert MacCrate, Educating a Changing Profession: From Clinic to Continuum, 64 Tenn. L. Rev3 (1997); Quigley, supra note, at 467.

[FN6]. Law schools with projects similar to Penn's "legal dispensary" included those at Cincinnati, Denver, George Washington, Harvard, Northwestern, Tennessee, and Yale Universities. See MacCrate, supra note 5, at 1103; Quigley, supra note 4, at 467.

[FN7]. See Blaze, supra note 1, at 940.

[FN8]. MacCrate, supra note 5, at 1103 (quoting College of Law, The Univ. of Tenn., Dedication 9 (1950)).

[FN9]. Id. at 1103-04, 1103 n.32.

[FN10]. Id. at 1103 n.32.

[FN11]. Margaret Martin Barry, Jon C. Dubin \& Peter A. Joy, Clinical Education for This Millennium: The Third Wave, 7 Clinical L. Rev. 1, 8 n.23 (2000).

[FN12]. Blaze, supra note 1, at 940 n.3.

[FN13]. See id. at 939.

[FN14]. Id. at 940 n.3.

[FN15]. Barry et al., supra note 11, at 3 n.6 ("There are numerous books, symposia, articles, and reports devoted to recounting, discussing, and examining the history of clinical legal education."); see, e.g., Blaze, supra note 1, at 939-942 (describing the development of the first law school clinical programs); MacCrate, supra note 5, at 1102-05 (outlining the progression of legal clinics prior to World War II); Report of the Committee on the Future of the In-House Clinic, 42 J. Legal Educ. 508, 511 (1992) (describing "the goals and teaching methods that many clinical teachers employ in their in-house, live-client clinics"); Report of Committee on Legal Aid Clinics, 1959 Ass'n Am. L. Schs. 121 (reporting on the integration of clinical work into the law school curriculum).

[FN16]. See Barry et al., supra note 11, at 30.

[FN17]. William M. Sullivan, Anne Colby, Judith Welch Wegner, Lloyd Bond \& Lee S. Shulman, Educating Lawyers: Preparation for the Profession of Law (2007).

[FN18]. Section of Legal Educ. and Admissions to the Bar, Am. Bar Ass'n, Standards for Approval of Law Schools, $\quad$ Standard $302(\mathrm{~b})(1) \quad$ (2007), available $\quad$ at 
tp://www.abanet.org/legaled/standards/20072008StandardsWebContent/2007-08\%20Standards\%C\% book.pdf [hereinafter ABA Standards].

[FN19]. Barry et al., supra note 11, at 18.

[FN20]. U.S. News and World Report, America's Best Graduate Schools 2008, Law Specialties: Clinical Training, http:// www.usnews.com/usnews/edu/grad/rankings/law/lawindex.php (follow "Clinical Training" hyperlink) (last visited Mar. 31, 2008) [hereinafter Clinical Training] (on file with the Tennessee Law Review).

[FN21]. Id. This rank is particularly impressive given the size of the community in which UT is situated. While the Knoxville population is estimated to be 182,337, U.S. Census Bureau, http://factfinder.census.gov/ (follow "Population Finder" hyperlink; then search "Knoxville, Tennessee") (last visited Jan. 31, 2008), the majority of the other schools appearing on the U.S. News Clinical Training ranking are located in much larger metropolitan areas with a concomitant increase in opportunities for clinical training fora and externship placements.

[FN22]. U.S. News \& World Report, America's Best Graduate Schools 2008, Law Specialties: Dispute Resolution, http:// www.usnews.com/usnews/edu/grad/rankings/law/lawindex.php (follow "Dispute Resolution" hyperlink) (last visited Nov. 9, 2007) [hereinafter Dispute Resolution] (on file with the Tennessee Law Review). U.S. News also ranked "Trial Advocacy" as a specialty for the first time in 2007. See U.S. News \& World Report, America's Best Graduate Schools 2008, Law Specialties: Trial Advocacy, http://www.usnews.com/usnews/edu/grad/rankings/law/lawindex.php (follow “Trial Advocacy" hyperlink) (last visited Nov. 9, 2007) [hereinafter Trial Advocacy] (on file with the Tennessee Law Review). Yet more blurring of distinctions? See also infra note 30 and accompanying text.

[FN23]. Jacobellis v. Ohio, 378 U.S. 184, 197 (1964) (Stewart, J., concurring). In borrowing Justice Stewart's oft-quoted phrase, I certainly do not intend to compare legal clinics or DR programs to Les Amants. See id. at 186 (majority opinion). However, one might argue that, like the claimed theme of that film, many clinics are devoted to the cause of freedom, and the work of most clinical programs is infused with uncertainty.

[FN24]. Marc S. Galanter, The Federal Rules and the Quality of Settlements: A Comment on Rosenberg's, The Federal Rules of Civil Procedure in Action, 137 U. Pa. L. Rev. 2231, 2232-33 (1989). Professor Galanter first coined "litigotiation" in Marc Galanter, Worlds of Deals: Using Negotiation to Teach About Legal Process, 34 J. Legal Educ. 268, 268 (1984).

[FN25]. Marc Galanter, The Quality of Settlements, 1988 J. Disp. Resol. 55, 82.

[FN26]. But see Carrie Menkel-Meadow, Pursuing Settlement in an Adversary Culture: A Tale of Innovation Co-opted or "The Law of ADR," 19 Fla. St. U. L. Rev. 1, 44 (1991). Rather than a process involving both cooperative and adversarial maneuvers, Professor Carrie Menkel-Meadow appears to view "litigotiation" as more of an adversarial process, one in which lawyers may use DR procedures such as negotiation and mediation as, for example, extra-procedural discovery mechanisms. See id. at 34-36, 33 n.167.

[FN27]. Leonard L. Riskin et al., Dispute Resolution and Lawyers 12 (3d ed. 2005).

[FN28]. Id.

[FN29]. Id. 
[FN30]. Because I am morbidly curious, I went straight to the source and e-mailed U.S. News \& World Report to discover what it believed was the distinction between a Clinical Training specialty and a Dispute Resolution specialty. They responded quite promptly, with this note: "[B]oth are separate course areas, clinical training is required as part [of] the law school curriculum[.] [D]ispute resolution is [a] separate area that deals with a narrower part [of] the law." E-mail from Bob Morse, U.S. News and World Report, to author (Sept. 11, 2007, 11:57:23 EDT) (on file with the Tennessee Law Review). I leave the reader to ponder that.

[FN31]. The fifteen schools noted for their Dispute Resolution specialty in 2007 are, in rank order: Pepperdine University, University of Missouri - Columbia, Hamline University, Harvard University, Ohio State University (Moritz), Marquette University, Yeshiva University (Cardozo), Pennsylvania State University (Dickinson), University of Oregon, Fordham University, Georgetown University, University of Nevada - Las Vegas (Boyd), Willamette University (Collins), Northwestern University, and Quinnipiac University. Dispute Resolution, supra note 22. The top Clinical Training programs are: Georgetown University, American University (Washington), New York University, Washington University in St. Louis, University of Maryland, University of New Mexico, CUNY - Queens College, Yale University, University of Michigan - Ann Arbor, Northwestern University, Catholic University of America (Columbus), Columbia University, Harvard University, University of California Los Angeles, Fordham University, University of California - Berkeley, Boston College, Seattle University, University of Tennessee - Knoxville, Northeastern University, Stanford University, University of Nevada - Las Vegas (Boyd), George Washington University, Yeshiva University (Cardozo), University of Chicago, University of the District of Columbia (Clarke), University of Baltimore, University of California (Hastings), Brooklyn Law School, Rutgers - Newark, Tulane University, University of Wisconsin - Madison, and William Mitchell College of Law. Clinical Training, supra note 20.

[FN32]. UT, for example.

[FN33]. Thirteen of the top fifteen DR schools have an institute, center, or identified program pertaining to dispute or conflict resolution. See Pepperdine University School of Law, Straus Institute for Dispute Resolution, http:// law.pepperdine.edu/straus/ (last visited Feb. 12, 2008); University of Missouri School of Law, Center for Dispute Resolution, http://law.missouri.edu/csdr/ (last visited Feb. 12, 2008); Hamline University School of Law, Dispute Resolution Institute, http://law.hamline.edu/adr/dispute-resolution-institute-hamline.html (last visited Feb. 12, 2008); Harvard Law School Program on Negotiation, http://www.pon.harvard.edu/ (last visited Feb. 12, 2008); Moritz College of Law, Alternative Dispute Resolution, http:// moritzlaw.osu.edu/programs/adr/ (last visited Feb. 12, 2008); Benjamin N. Cardozo School of Law, Kukin Program for Conflict Resolution, http:// www.cardozo.yu.edu/directory.aspx?page=3 (follow "Kukin Program" hyperlink) (last visited Feb. 12, 2008); Penn State Dickinson School of Law, Institute of Arbitration Law and Practice, http://www.dsl.psu.edu/academics/arbitration.cfm (last visited Feb. 12, 2008); University of Oregon, Appropriate Resolution Center, http://www.law.uoregon.edu/org/adr/ (last visited Feb. 12, 2008); Fordham Law, Feerick Center, http://law.fordham.edu/feerickcenter.htm (last visited Feb. 12, 2008); Georgetown Law, Georgetown-Hewlett Program in Conflict Resolution and Legal Problem Solving, http://www.law.georgetown.edu/hewlett/ (last visited Feb. 12, 2008); Willamette University College of Law, Center for Dispute Resolution, http://www.willamette.edu/wucl/cdr/ (last visited Feb. 12, 2008); Northwestern University School of Law, Program on Negotiation and Mediation, http:// www.law.northwestern.edu/legalclinic/simulation/negotiations/ (last visited Feb. 12, 2008); Quinnipiac University School of Law, Center on Dispute Resolution, http://law.quinnipiac.edu/x127.xml (last visited Feb. 12, 2008).

[FN34]. Seven of the fifteen top DR schools publish a DR-related specialty journal. See Pepperdine University 
School of Law, Dispute Resolution Law Journal, tp://law.pepperdine.edu/organizations/dispute_resolution_law_journal/ (last visited Feb. 12, 2008); University of Missouri School of Law, Center of Dispute Resolution Journal, http:// www.law.missouri.edu/csdr/journal/ (last visited Feb. 12, 2008); Harvard Law School Program on Negotiation, Harvard Negotiation Law Review, http:// www.pon.harvard.edu/publications/hnlr.php (last visited Feb. 12, 2008); Ohio State Journal on Dispute Resolution, http://moritzlaw.osu.edu/jdr/ (last visited Feb. 12, 2008); Cardozo Journal of Conflict Resolution, http:// www.cojcr.org/ (last visited Feb. 12, 2008); Penn State Dickinson School of Law, World Arbitration and Mediation Review, http:// www.dsl.psu.edu/publications/worldarbitration/index.cfm (last visited Feb. 12, 2008); Willamette Journal of International Law and Dispute Resolution, http:// www.willamette.edu/wucl/journals/wjildr/ (last visited Feb. 12, 2008).

[FN35]. Ten of the top fifteen DR schools offer a certificate or Master's degree in DR. See Pepperdine University School of Law, JD/MDR, http:// law.pepperdine.edu/academics/joint_degree_programs/jdmdr.html (last visited Feb. 12, 2008); University of Missouri School of Law, Master of Law in Dispute Resolution, http://www.law.missouri.edu/llm/ (last visited Feb. 12, 2008); Hamline University School of Law, Certificate Program in Dispute Resolution, http://law.hamline.edu/llm/dr-certificate.html (last visited Feb. 12, 2008); Moritz College of Law, Certificate in Dispute Resolution, http:// moritzlaw.osu.edu/programs/adr/certificate.php (last visited Feb. 12, 2008); Marquette University, Center for Dispute Resolution, Law School Joint Program, http://www.marquette.edu/disputeres/programs/joint.shtml (last visitied Mar. 27, 2008); Kukin Program for Conflict Resolution, Certificate, http:// www.cardozo.yu.edu/directory.aspx?page=3 (follow "Kukin Program" hyperlink, then follow "Certificate" hyperlink) (last visited Feb. 12, 2008); Penn State Dickinson School of Law, Certificate in Dispute Resolution and Advocacy, http://www.dsl.psu.edu/academics/certificate.cfm (last visited Feb. 12, 2008); University of Oregon, Conflict and Dispute Resolution Program, http:// conflict.uoregon.edu/dual.html (last visited Feb. 12, 2008); Willamette University College of Law, Certificate Program in Dispute Resolution, http:// www.willamette.edu/wucl/cdr/certificate/ (last visited Feb. 12, 2008); Quinnipiac University School of Law, Civil Advocacy and Dispute Resolution, http://law.quinnipiac.edu/x89.xml (last visited Feb. 12, 2008).

[FN36]. Virtually all of these schools have one of more faculty members with national reputations in the field.

[FN37]. ABA Standards, supra note 18, Standard 302(b)(1).

[FN38]. Id. at Interpretation 302-5.

[FN39]. Report of the Committee on the Future of the In-House Clinic, supra note 15, at 511.

[FN40]. Elliott S. Milstein, Clinical Legal Education in the United States: In-House Clinics, Externships, and Simulations, 51 J. Legal Educ. 375, 376 (2001). Professor Milstein defines these three branches as follows: Inhouse live-client clinics are built around an actual law office, usually located in the law school, that exists for the purpose of providing students with a faculty-supervised setting within which to practice law and learn from the experience. Students learning in externship programs are placed in professional settings external to the law school, including law offices within governmental agencies and nongovernmental organizations. Law schools use the students' experience in those offices as the basis for teaching and learning. Simulation is a teaching method in which students are put into simulated lawyer roles to perform some aspect of the lawyering process in a controlled setting. Each of these uses the students' experiences as the subject matter for analysis, both within and outside the classroom. Id. (footnotes omitted). 
[FN41]. Richard J. Wilson, Training for Justice: The Global Reach of Clinical Legal Education, 22 Penn St. Int'1 L. Rev. 421, 423 (2004).

[FN42]. I deliberately have not addressed the debate that still rages about the role of service in clinical programs. Some, while acknowledging persistent arguments in favor of public service work, have nevertheless pronounced that debate settled. See Frederick M. Hart \& J. Michael Norwood, Key Parameters of the Clinical Method of Study, in Professional Education in the United States: Experiential Learning, Issues, and Prospects 86, 90-92 (Solomon Hoberman \& Sidney Mailick eds., 1994). Clearly they are not reading the same material or attending the same conferences as am I.

[FN43]. I am not alone in my admiration for Fran; she was recently honored with the Society of American Law Teachers (SALT) Great Teacher Award. University of Tennessee College of Law, News and Events, http:// www.law.utk.edu/news/AnsleySALT.htm (last visited Feb. 10, 2008).

[FN44]. Fran and our colleague Cathy Cochran of the UT Law Library faculty created a great website to exhibit a permanent collection of selected student projects from Fran's community-based field work courses. See University of Tennessee College of Law Student Field Projects in Community Law, http:// www.law.utk.edu/Library/teachinglearning/default.html (last visited Feb. 12, 2008).

[FN45]. Barry et al., supra note 11, at 18.

[FN46]. "I" in this context is a truly misleading euphemism and used in the Royal "We" sense. Without the able assistance of my amazing administrative assistant, the poet Monica Miller, these data would still appear in raw form on each law school's individual website.

[FN47]. I often found it difficult to distinguish between "in-house clinics" and externships based upon a review of course names alone. However, the common conception of these terms is as follows. The term "in-house clinic" typically refers to programs in which students are certified by a state or federal court to act as lawyers for real clients with real legal problems under the close supervision of licensed attorneys, who act as counsel of record. See Milstein, supra note 40 , at 18 . The supervising attorneys may be faculty members or local lawyers who are adjuncts to the faculty. See Philip G. Schrag, Constructing a Clinic, 3 Clinical L. Rev. 175, 186 (1996). The term "externship," on the other hand, refers to a program in which students perform legal work in various capacities in a governmental or nonprofit agency or office. See Milstein, supra note 40, at 380. For example, an externship student may work in a judge's chambers or a prosecutor's office. These students are supervised by lawyers regularly employed in the office. See id. Law school faculty maintain a role in externships, but typically are not directly involved in representing externship clients. See id. Clinics and externships offer students different experiences and opportunities. See J.P. Ogilvy, Guidelines with Commentary for the Evaluation of Legal Externship Programs, 38 Gonz. L. Rev. 155, 159-60 (2003). "In-house clinics are usually organized to provide students with primary responsibility for a case, while externship students have that responsibility less often, depending on the nature of the placement." Harriet N. Katz, Reconsidering Collaboration and Modeling: Enriching Clinical Pedagogy, 41 Gonz. L. Rev. 315, 318 (2006).

[FN48]. Unless otherwise noted, all comments in this Essay about clinical offerings at the top law schools are based on my analysis of the data I gathered through an extensive review of the schools' web sites. The list of the top 100 law schools is available at U.S. News \& World Report, America's Best Graduate Schools 2008, Top Law Schools, http:// www.usnews.com/usnews/edu/grad/rankings/law/lawindex.php (follow "Top Law Schools" hyperlink) (last visited Feb. 12, 2008) (on file with the Tennessee Law Review). My data are on file with the 
Tennessee Law Review.

[FN49]. See, e.g., Boston University School of Law, Civil Litigation Program, http://www.bu.edu/law/prospective/jd/clinics/civil.html (last visited Feb. 12, 2008).

[FN50]. See, e.g., University of San Diego School of Law, Small Claims Clinic, http:// www.sandiego.edu/usdlaw/about/legalassist/clinics/studentinfo/smallclaims.php (last visited Feb. 12, 2008).

[FN51]. See, e.g., CUA Columbus School of Law, General Practice Clinic, http://law.cua.edu/clinics/cle/clinics_general.cfm (last visited Feb. 12, 2008).

[FN52]. See, e.g, Duke University Law School, Death Penalty Clinic, http:// www.law.duke.edu/deathpenalty/ (last visited Feb. 12, 2008).

[FN53]. See, e.g., William and Mary School of Law, Innocence Project Clinic, http://www.wm.edu/law/academicprograms/curriculum/experiences/law747-01.shtml (last visited Feb. 12, 2008).

[FN54]. See, e.g., Indiana University School of Law, Inmate Legal Assistance Project, http://www.law.indiana.edu/students/groups/ilap/index.shtml (last visited Feb. 12, 2008); Indiana University School of Law, Community Legal Clinic, http://www.law.indiana.edu/curriculum/programs/clinics/community_ legal.shtml (last visited Feb. 12, 2008).

[FN55]. See, e.g., McGeorge School of Law, On-Campus Clinics, http:// www.mcgeorge.edu/x691.xml (last visited Feb. 12, 2008).

[FN56]. See, e.g., University of Michigan Law School, Child Advocacy Law Clinic, http:// www.law.umich.edu/centersandprograms/clinical/calc/Pages/default.aspx (last visited Feb. 12, 2008).

[FN57]. See, e.g., University of Texas School of Law, Children's Rights Clinic, http://www.utexas.edu/law/academics/clinics/childrens/ (last visited Feb. 12, 2008).

[FN58]. See, e.g., Pepperdine University School of Law, Special Education Advocacy Clinic, http://law.pepperdine.edu/clinical/special_education_advocacy_clinic/ (last visited Feb. 12, 2008).

[FN59]. See, e.g., University of Virginia School of Law, Clinics, http:// www.law.virginia.edu/html/academics/clinics.htm\#immigration (last visited Feb. 12, 2008).

[FN60]. See, e.g., University of California Hastings College of the Law, Civil Justice Clinic, http://www.uchastings.edu/?pid=127 (last visited Feb. 12, 2008).

[FN61]. See, e.g., University of Toledo College of Law, Dispute Resolution Clinic, http://www.utlaw.edu/students/clinics/disputeresolution.htm (last visited Feb. 12, 2008).

[FN62]. See, e.g., University of South Carolina School of Law, Environmental Law Program, http://www.law.sc.edu/environmental/ (last visited Feb. 12, 2008).

[FN63]. See, e.g., William and Mary School of Law, International Law Clinic: Iraqi Special Tribunal, http:// www.wm.edu/law/academicprograms/curriculum/experiences/law748-01.shtml (last visited Feb. 12, 2008); see also University of Virginia School of Law, News and Events, Law Students Contribute to Iraqi Tribunals, 
www.law.virginia.edu/html/news/2006_fall/iraqiclinic.htm (last visited Mar. 31, 2008) (describing a clinical experience offered in the fall of 2006 and taught by a visiting professor).

[FN64]. See, e.g., Boalt Hall School of Law, Promoting Human Rights Within the United States, http://www.law.berkeley.edu/clinics/ihrlc/rights_in_us.html (last visited Feb. 12, 2008); Yale Law School, Hurricane Relief Project, http://www.law.yale.edu/academics/1210.asp (last visited Feb. 12, 2008).

[FN65]. See, e.g., Columbia Law: Clinics, http://www.law.columbia.edu/llm_jsd/grad_studies/courses/clinics/ (last visited Feb. 12, 2008); Legal Services of Harvard Law School: Gay, Lesbian, Bisexual and Transgender (GLBT) Law Clinic, http://www.law.harvard.edu/academics/clinical/lsc/clinics/gay.htm (last visited Feb. 12, 2008).

[FN66]. While not among the top 100 law schools in the U.S. News rankings, the University of the District of Columbia David A. Clarke School of Law is listed as having one of the top clinical programs. See Clinical Training, supra note 20. One of its clinics focuses on "provid[ing] comprehensive, holistic legal services to families with AIDS." University of the District of Columbia, David A. Clarke School of Law, HIV/AIDS Legal Clinic, http:// www.law.udc.edu/programs/hiv/index.html (last visited Feb. 12, 2008).

[FN67]. See The George Washington University Law School, Vaccine Injury, http://www.law.gwu.edu/Academics/Clinical+Programs/Vaccine+Injury+Clinic.htm (last visited Feb. 12, 2008).

[FN68]. See, e.g., University of Maryland School of Law, Tobacco Control Clinic, http://www.law.umaryland.edu/course_info.asp?coursenum=534D (last visited Feb. 12, 2008).

[FN69]. See, e.g., University of San Francisco, USF Law Clinics, http:// www.usfca.edu/law/academics/shared-content/In-HouseClinics.html (last visited Feb. 12, 2008); Pace Law School: Investor Rights Clinic, http:// www.pace.edu/page.cfm?doc_id=23714 (last visited Feb. 12, 2008).

[FN70]. See, e.g., Seattle University School of Law, Clinical Law Courses, http://www.law.seattleu.edu/clinic/courses?mode=standard\#artslegal (last visited Feb. 12, 2008).

[FN71]. See University of Washington School of Law, Sexual Violence and the Law Clinic, http://www.law.washington.edu/clinics/SexualViolence.html (last visited Feb. 12, 2008).

[FN72]. I identified seventeen such clinics. See, e.g., Rutgers School of Law, Community Law Clinic, http://law.newark.rutgers.edu/clinics_ community.html (last visited Feb. 12, 2008).

[FN73]. There are fifteen tax-related clinics. See, e.g., American University Washington College of Law, Janet R. Spragens Federal Tax Clinic, http://www.wcl.american.edu/clinical/federal.cfm (last visited Feb. 12, 2008).

[FN74]. Fifteen clinics focus on health law. See, e.g., University of San Diego School of Law, Mental Health Clinic, http:// www.sandiego.edu/usdlaw/about/legalassist/clinics/studentinfo/mentalhealth.php (last visited Feb. 12, 2008).

[FN75]. There are fifteen clinics devoted to this subject. See, e.g., Georgetown Law, The International Women's Human Rights Clinic (IWHRC), http:// www.law.georgetown.edu/clinics/iwhrc/ (last visited Feb. 12, 2008). At UT's Symposium, Professor Susan Deller Ross described the amazing clinic she directs at Georgetown, the International Women's Human Rights Clinic. While a number of schools offer clinics involving international hu- 
man rights, Professor Ross's particular focus on women's human rights appears unique.

[FN76]. I identified fourteen legislative advocacy clinics. See, e.g., Yale Law School: Legislative Advocacy Clinic, http:// www.law.yale.edu/academics/1217.asp (last visited Feb. 12, 2008).

[FN77]. Thirteen clinics focus on administrative and government benefits. See, e.g., Penn State Dickinson School of Law: Disability Law Clinic, http:// www.dsl.psu.edu/clinic/disability.cfm (last visited Feb. 12, 2008).

[FN78]. See generally Peter H. Bloch, Seeking the Ideal Form: Product Design and Consumer Response, J. Marketing, July 1995, at 16 (1995) (discussing consumer response to attractive product form).

[FN79]. University of Tennessee College of Law, Clinical Programs: Mediation Clinic, http://www.law.utk.edu/departments/CLINIC/clinicmediation.htm (last visited Feb. 12, 2008). While I have directed this clinic for several years, it was created by the much honored Grayfred Gray and has attracted several other excellent directors during its existence. Grayfred is a legend in mediation circles in Tennessee and beyond. He recently received the first annual "Grayfred Gray Public Service Mediation Award," an award named in honor of "his original and lasting contributions to mediation awareness in Tennessee." Lipscomb University, Mayor Celebrates Mediation Day with ICM on Campus, http:// news.lipscomb.edu/filter.asp?SID=14\&fi_key=724\&co_key=12551 (last visited Feb. 12, 2008). He retired from the UT faculty in 2001 and currently serves as the Training Director of the Lancaster Mediation Center. See Lancaster Mediation Center, Who We Are, http://www.lancmed.org/staff.html (last visited Feb. 12, 2008).

[FN80]. ABA Standards, supra note 18, Standard 405(c).

[FN81]. Video recording: Charles Miller Legal Clinic 60th Anniversary Celebration, held by the University of Tennessee College of Law, Session IV: Expanding Clinical Experiences (Sept. 15, 2007), available at http:// mediabeast.ites.utk.edu/mediasite4/Catalog/ (follow "Charles Miller Legal Clinic-60th Anniversary Celebration" hyperlink in sidebar, then follow "Session IV" hyperlink) [hereinafter Video recording, Session IV].

[FN82]. Professor Barry and her colleagues discuss this issue in more detail: Presently, there is tenure or contract status information on 789 clinicians, with 134 out of 183 schools reporting at least one clinician who was tenured or on tenure-track; thirty-one schools reporting at least one clinician who was clinical tenured or on the clinical tenure track; seventy-one schools reporting at least one clinician who was on a long-term contract; and 112 schools reporting at least one clinician who was on a short-term contract. With respect to tenure, 245 clinicians reported that they had tenure, and ninety-three clinicians reported that they were tenure-track but had not yet attained tenure. In addition, twenty-nine clinicians reported that they had clinical tenure and twenty-five clinicians reported that they were clinical tenure-track but had not yet attained clinical tenure. In terms of those clinical faculty with contract rather than tenure status, 161 clinicians reported that they were on long-term contracts of three years or more, and 236 clinicians reported that they were on short-term contracts. Barry et al., supra note 11, at 31 (footnotes omitted). See generally Peter A. Joy \& Robert R. Kuehn, The Evolution of ABA Standards for Clinical Faculty, 75 Tenn. L. Rev. 183 (2008) (providing a detailed history of the evolution of the ABA Standards related to clinical faculty tenure and participation in law school governance).

[FN83]. Professor Laura Rovner chose the term "classroom faculty" to describe faculty who do not teach in the clinic, explicitly acknowledging that the term "may not accurately reflect how some such faculty view themselves and their teaching." Laura L. Rovner, The Unforeseen Ethical Ramifications of Classroom Faculty Participation in Law School Clinics, 75 U. Cin. L. Rev. 1113, 1114 n.1 (2007). In so identifying this group of law 
faculty, Professor Rovner confronted her own lexical challenges as she considered alternative labels, including "stand-up," "podium," and "doctrinal"-all of which she decided were problematic in one way or another, for example, because these terms imply "that clinical teaching is not theoretical, academic, doctrinal, etc." Id.

[FN84]. Id. at 1114.

[FN85]. ABA Standards, supra note 18, Standard 302(b)(1).

[FN86]. Id.

[FN87]. Video recording, Session IV, supra note 81.

[FN88]. Id.

[FN89]. Rovner, supra note 83, at 1114. Furthermore, Professor Rovner explores another definitional conundrum in her article: whether a law school clinic constitutes a law firm as described by Model Rule of Professional Conduct 1.0(c). See Rovner, supra note 83, at 1122-23. See generally Model Rules of Prof'l Conduct R. 1.0(c) (6th ed. 2007) (defining "firm" and "law firm"). This question is relevant to her exploration of the ethical issues inherent in involving classroom instructors in clinical programs. See generally Rovner, supra note 83, at 1143-69 (discussing the ethical ramifications of classroom faculty participation in clinical courses). As it exceeds the scope of my Essay, I commend Professor Rovner's Article to the interested reader's attention.

[FN90]. See Rovner, supra note 83, at 1143-50.

[FN91]. Id. at 1144.

[FN92]. Id. at 1144-45.

[FN93]. Id. Commentators have noted the irony of this result when one considers the high regard in which law professors are often held within the legal profession. Id. at 1145 (quoting Jett Hanna, Moonlighting Law Professors: Identifying and Minimizing the Professional Liability Risk, 42 S. Tex. L. Rev. 421, 433-34 (2001)).

[FN94]. See Rovner, supra note 83, at 1150-65.

[FN95]. See id. at 1150-56.

[FN96]. See id. at 1156-62.

[FN97]. See id. at 1162-65.

[FN98]. See id. at 1165-69.

[FN99]. Id. at 1166.

[FN100]. See id. at 1166-68.

[FN101]. Schrag, supra note 47, at 211.

[FN102]. See id. at 211-12. 
[FN103]. Id. at 187.

[FN104]. Id.

[FN105]. Id.

[FN106]. Id. at 212.

[FN107]. Id.

[FN108]. ABA Standards, supra note 18, Standard 405(c).

[FN109]. Cf. Schrag, supra note 47, at 186, 188-89 (noting the possibility of adjunct involvement and discussing "two possible competing models for relations among clinic staff[:] the hierarchical model and the collaborative model"); ABA Standards, supra note 18, Interpretation 405-8 ("A law school shall afford to full-time clinical faculty members participation in faculty meetings, committees, and other aspects of law school governance in a manner reasonably similar to other full-time faculty members. This Interpretation does not apply to those persons referred to in the last sentence of Standard 405(c) [i.e., short-term, non-faculty clinic staff].”).

[FN110]. Schrag, supra note 47, at 186.

[FN111]. For those interested in esoterica, this reference, too, suffers from some interpretive re-categorization. Most of us have heard the phrase "angels dancing on the head of a pin." However, the actual quote appears to be, "[S]ome who are far from Atheists, may make themselves merry, with that Conceit of Thousands of Spirits, dancing at once upon a Needle[']s Point." Ralph Cudworth, The True Intellectual System of the Universe 778 (Garland Publishing 1978) (1678).

[FN112]. See, e.g., discussion supra note 42 and accompanying text.

[FN113]. Video recording: Charles Miller Legal Clinic 60th Anniversary Celebration, held by the University of Tennessee College of Law, Session V: The Future of Clinics and the Law School Curricula (Sept. 15, 2007), available at http://mediabeast.ites.utk.edu/mediasite4/Catalog/ (follow "Charles Miller Legal Clinic-60th Anniversary Celebration" hyperlink in sidebar, then follow "Session V" hyperlink).

[FN114]. Sullivan et al., supra note 17, at 121, 132.

75 Tenn. L. Rev. 343

END OF DOCUMENT 